\title{
Bacterial consortium for copper extraction from sulphide ore consisting mainly of chalcopyrite
}

\author{
E. Romo ${ }^{1}$, D.F. Weinacker ${ }^{1}$, A.B. Zepeda ${ }^{1}$, C.A. Figueroa ${ }^{1}$, \\ P. Chavez-Crooker ${ }^{2}$, J.G. Farias ${ }^{1}$ \\ ${ }^{1}$ Departamento de Ingeniería Química, Facultad de Ingeniería, Ciencias y Administración, \\ Universidad de La Frontera, Temuco, Chile. \\ ${ }^{2}$ Biotecnologías Aguamarina S.A., Antofagasta, Chile.
}

Submitted: September 11, 2012; Approved: December 10, 2012.

\begin{abstract}
The mining industry is looking forward for bacterial consortia for economic extraction of copper from low-grade ores. The main objective was to determine an optimal bacterial consortium from several bacterial strains to obtain copper from the leach of chalcopyrite. The major native bacterial species involved in the bioleaching of sulphide ore (Acidithiobacillus ferrooxidans, Acidithiobacillus thiooxidans, Leptospirillum ferrooxidans and Leptospirillum ferriphilum) were isolated and the assays were performed with individual bacteria and in combination with At. thiooxidans. In conclusion, it was found that the consortium integrated by At. ferrooxidans and At. thiooxidans removed $70 \%$ of copper in 35 days from the selected ore, showing significant differences with the other consortia, which removed only $35 \%$ of copper in 35 days. To validate the assays was done an escalation in columns, where the bacterial consortium achieved a higher percentage of copper extraction regarding to control.
\end{abstract}

Key words: bioleaching, Acidithiobacillus ferrooxidans, Acidithiobacillus thiooxidans.

\section{Introduction}

While world demand for copper is growing, the minerals industry is increasingly faced with the need to process low-grade ores, overburden and waste from current mining operations (Watling, 2006). Biotechnology is an area that has produced a considerable increase in recent years, mainly because occurrence of microbiological techniques and molecular biology, which help to isolate and identify the species that are related to the dissolution of minerals (Rawlings and Johnson, 2007). The economic extraction of copper from low-grade ores requires low-cost processing methods such as in situ, dump and heap leaching. Bacterially assisted heap leaching of low-grade copper sulphides is a developing technology that has been applied successfully for the extraction of copper from secondary sulphide minerals such as chalcocite at a number of operations worldwide. However, heap bioleaching of the refractory primary copper sulphide chalcopyrite, has yet to be implemented at commercial scale (Watling, 2006).

The predominant metal-sulfide-dissolving microorganisms are extremely acidophilic bacteria (meaning organisms thriving at $\mathrm{pH}$ values below 3 ) that are able to oxidize either inorganic sulfur compounds and/or iron (II) ions (Rohwerder et al., 2003). The first isolates of extremely acidophilic sulfur- and/or iron (II)-oxidizing bacteria are the mesophilic At. thiooxidans and At. Ferrooxidans (Rohwerder et al., 2003). Most microbiological researches were developed utilizing known iron- and sulphuroxidizing bacteria, either as single strains or in mixed cultures. However, in many instances, endogenous bacteria in the ore are not excluded and may thus contribute to bioleaching. Indeed, it is often noted that endogenous bacteria, being acclimatized to high levels of selected metals in their environment, are more effective as bioleaching catalysts. The acclimatization of bacteria to a particular mineral system, by subjecting them to progressively greater amounts

Send correspondence to J.G. Farias. Departamento de Ingeniería Química, Facultad de Ingeniería, Ciencias y Administración, Universidad de La Frontera, Temuco, Chile. E-mail: jorge.farias@ufrontera.cl. 
of the major elements, is common practice in test work (Watling, 2006). The combination of different bioleaching bacterial species is known as "bacterial consortium". It is known that bacterial consortia are modified according to specific type of mineral and it environmental conditions (Rawlings and Johnson, 2007). Each kind of ore has unique characteristics, either a particular strain or a consortium of bacterial strains, which serves very well for a given mineral, but it is useless against another type of ore (Okibe and Johnson, 2004). That is why despite that already they have isolated and patented a large number of bioleaching strains; the industry continues investing in a variety of research to find new strains that achieve optimize the bacterial bioleaching (Rawlings and Johnson, 2007).

In cooper industry, Chalcopyrite $\left(\mathrm{CuFeS}_{2}\right)$ is the most abundant and refractory copper-bearing mineral worldwide and also the principal mineral source from which copper is recovered commercially (Xia et al., 2012). That also converts it in the main copper sulphide mineral mined at bioleaching operations. Some of the chalcocite heap operations began as oxide (chemical) leach operations and were converted to bioleach (oxidative) by heap aeration and/or inoculation, when the oxidized ore was depleted. However, even if bacterial activity is not facilitated, microbial assisted air oxidation of iron (II) and sulphur will contribute to copper extraction if sulphide minerals are present in a heap (Watling, 2006). Thus, is important to know whether, for a given process and mineral, if there is one ideal combination of micro-organisms or whether combinations of different microbial isolates (or species) are likely to be as efficient as each other once they are equally adapted to the mineral in synergic activity. The question arises, therefore, as to whether the microbial populations in commercial operations are the most suitable and efficient consortia (and the most effective strains and species) that could be used for processing different minerals (Rawlings and Johnson, 2007). The objective of this study was isolate a bacterial consortium present in mineral composed mainly of chalcopyrite-bornite and determine which of this isolated consortiums was best suited for the extraction of copper from sulphide ore samples.

\section{Materials and Methods}

\section{Characteristics of the mineral}

A single sample of sulphide ore was collected from the region of Atacama, Chile, specifically from the Mining Company El Abra. This mineral presented a mineralogy of $0.64 \%$ from the total $\mathrm{Cu}$ (of which $70 \%$ corresponded to chalcopyrite and bornite $30 \%$ ), $0.8 \%$ pyrite, $43.7 \%$ quartz, $14.6 \% \mathrm{~K}$-feldspar, $11 \%$ plagioclase, $16.1 \%$ of muscovite/sericite, $2.41 \%$ biotite, $2.1 \%$ chlorite, $3 \%$ smectite/kaolinite, $1.3 \%$ iron and $4.35 \%$ of diverse compounds in very small amounts (less than $0.5 \%$ ).

\section{Enrichment of different bacterial consortia}

For the enrichment of the different bacterial species from the sulphide ore studied, were used $250 \mathrm{~mL}$ Erlenmeyer flasks with $100 \mathrm{~mL}$ of the culture medium for each bacterial species described by the following authors: Leptospirillum ferrooxidans (Battaglia et al., 1994); Acidithiobacillus ferrooxidans, (Tuovinen and Kelly, 1973); Leptospirillum ferriphilum at a temperature of $45^{\circ} \mathrm{C}$ (Battaglia et al., 1994); Acidithiobacillus thiooxidans (Nakamura et al., 1997). Then, the flasks with enrichment media for the various species were incubated in a thermo regulated shaker (Lab Line brand model No. 3528-5), at a temperature of $30{ }^{\circ} \mathrm{C}$ (except for the enrichment of Leptospirillum ferriphilum, where the temperature for growth was $45{ }^{\circ} \mathrm{C}$ ). All cultures were grown at a stirring speed of $3.13 \mathrm{~g}$. It was performed a cell count in the Neubauer chamber (Brand Braun) with a phase contrast microscope (Nikkon brand model E-3200), an operation that was performed with a frequency of 48 hours; after the bacterial concentration reached its plate $\left(1 \times 10^{9}\right.$ cells $\left./ \mathrm{mL}\right)$, we proceeded to draw $10 \mathrm{~mL}$ of bacterial culture and inoculated into $90 \mathrm{~mL}$ of media-specific bacterial species. The above step was repeated for at least 10 times to achieve isolation of the different bacterial consortia (Battaglia et al., 1994).

\section{Measurement of chemical parameters}

The $\mathrm{pH}$ and the electrochemical potential of the Bioleaching test in flasks were checked by a portable $\mathrm{pH} / \mathrm{mV} /$ Temperature Meter (WTW model 340i). The test started with different values of electrochemical potential due to the different culture media for the enrichment of each bacterium, which were inoculated with a concentration of $10 \%$ of the total volume of the test according to the method of Xia et al. (2008). For the measurement of copper extraction was performed a chemical analysis with an atomic absorption equipment (Perkin Elmer model 3110).

\section{Bioleaching tests in flasks}

Once enriched the bacterial consortia present in the ore, we performed the method described by Xia et al. (2008). It was used $250 \mathrm{~mL}$ Erlenmeyer flasks, to which were administered an amount of $5 \mathrm{~g}(5 \% \mathrm{w} / \mathrm{v})$ copper sulphide ore (Bulk-2) with a particle size distribution between 1180 to $1700 \mu \mathrm{m}$ in diameter, $90 \mathrm{~mL}$ of medium $(3 \mathrm{~g} / \mathrm{L}$ $\left(\mathrm{NH}_{4}\right)_{2} \mathrm{SO}_{4}, 0.1 \mathrm{~g} / \mathrm{L} \mathrm{KCl}, 0.5 \mathrm{~K}_{2} \mathrm{HPO}_{4}, 0.5 \mathrm{MgSO}_{4} \times 7 \mathrm{H}_{2} \mathrm{O}$, $\left.0.01 \mathrm{Ca}\left(\mathrm{NO}_{3}\right)_{2}\right)$ and $10 \mathrm{~mL}$ of bacterial inoculum with a viability above $95 \%$ for each species through the use of the kit LIVE/DEAD ${ }^{\circledR}$ from Invitrogen. Then the flasks of all tests (in triplicate) were incubated for 35 days in a thermo regulated shaker (model MRC brand TU-454) at a constant temperature of $30^{\circ} \mathrm{C}$ and constant agitation of $170 \mathrm{rpm}$. 


\section{Bioleaching tests in columns}

Finally, it was performed a scaling on columns of $1.5 \mathrm{~m}$, with an inoculation of $5 \%$ of the total volume of solution that passed through the column $v s$. a control column without inoculation in a period of 55 days of operation.

\section{Statistic Analysis}

For the statistic analysis it was used ANOVA and the Tukey's Post Hoc Test. It was considered a $p<0.05$. Data were analyzed by Software GraphPad Prism v. 5.0 (San Diego, 189 California).

\section{Results and Discussion}

\section{Copper extraction level}

In these tests it was studied the ability of copper extraction by different bacterial consortia and their interaction with sulphide ore of a mining company. The species used have a viability of over $95 \%$ for the development of all tests (data not shown); which ensures that the inoculated bacteria were viable for the development of tests in flasks. Figure 1 shows that the bacterial consortium that achieve a greater extraction of copper since day 10 until the end, was composed by At. ferrooxidans with. At. thiooxidans. This is in line with the reported by Norris et al. (2000), who notes that for the dissolution of chalcopyrite usually requires iron- and sulfur-oxidizing bacteria. However, this does not apply by combining the iron oxidizing bacteria $L$. ferrooxidans with the sulfur oxidizing bacteria At. thiooxidans, since the combination does not produced an increase in the extraction of copper. In fact, the amount of copper extracted at the end of the test from each bacterium is the same compared to when they are combined.

The consortium enriched for At. thiooxidans started with the extraction of small amounts of copper, but this amount increased as time went on. This may be due to the appearance of iron oxidizing bacteria during the development of the test, which were in the mineral surface and began to grow. It must be taken into account that the industrial process does not require sterilization and will always exist native bacterial species on the mineral surface that may affect the behavior of the inoculated bacteria. In this case, the

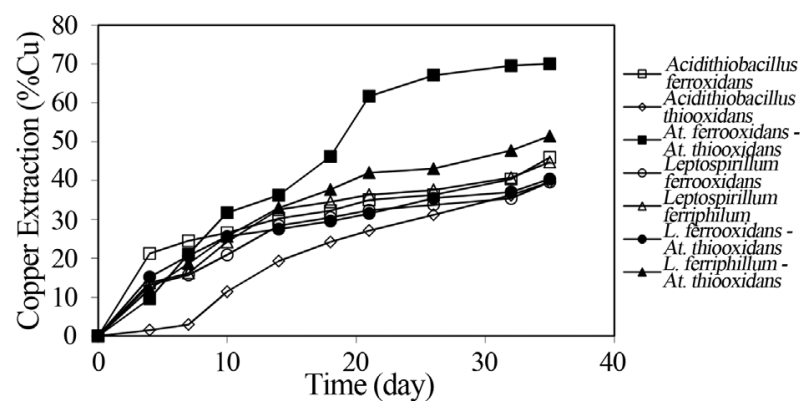

Figure 1 - Level of copper extraction through time. Percentage of copper extraction by different bacterial consortia through time. concentration of every consortium isolated was over $90 \%$ (data not shown). However, not being $100 \%$ pure cultures is likely that the bacteria present in low amounts affects the results. Also, by combining both bacterial consortia ( $L$. ferriphilum and At. thiooxidans), it's possible to increment the extraction percentage of copper in ore. From this two bacteria, the most important is L. ferriphilum, a bacterium moderately thermophilic and, as Coram and Rawlings (2002), is found primarily in the operation of stirred tanks of arsenopyrite at $40{ }^{\circ} \mathrm{C}$ temperature. The test of bioleaching in shake flasks was carried out at a controlled temperature of $30{ }^{\circ} \mathrm{C}$, therefore temperature was not optimal for this bacterial consortium. However, at the end of the test in Figure 2, the consortium achieved a good extraction of copper, being in second place. There is a difficulty in the extraction of copper from different bacterial consortium, due to the large amount of chalcopyrite present in the mineral studied $(70 \%$ total $\mathrm{Cu})$.

Of this aspect, Klauber et al. (2001) notes that in the case of chalcopyrite, both sulfur and iron compounds of this mineral $\left(\mathrm{CuFeS}_{2}\right)$ contain products that, when the dissolution occurs, is responsible for the low speed in the leaching reaction. Subsequently, Tshilombo et al. (2002) indicated the formation of so-called "passivation of chalcopyrite", in which is deposited a layer of elemental sulfur in a stage of dissolution of this. The layer would create a strong inhibition on the transfer of ferrous ions on the surface of this mineral polarized. According to Dreisinger et al. (1995), this proceeds by the formation of intermediates polisulphuretted on the surface of chalcopyrite. Regarding this, the bacterial consortium that achieved the greater extraction of copper from sulphulretted ore (Figure 2), was the one that consisted of consortia At. ferrooxidans with At. thiooxidans, making a 70\% extraction of copper in the final

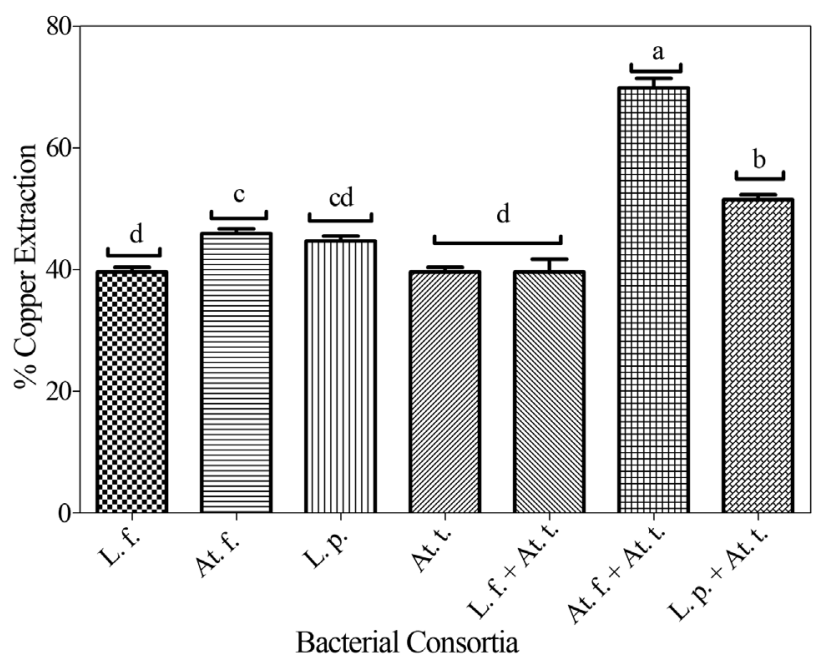

Figure 2 - Final level of copper extraction. Represents the percentage of copper extraction at the end of the test (day 35) by different bacterial consortia; Lf: Leptospirillum ferrooxidans; At.f.: Acidithiobacillus ferrooxidans, Lp: Leptospirillum ferriphilum; At.t.: Acidithiobacillus thiooxidans. (E.E.: $\mathrm{p}<0.05)$. 
test. The consortium presented a statistically significant difference from the rest of the tests. This, as described by Meyer et al. (2002), who notes that At. ferrooxidans clearly possesses a chemosensor called chemotaxis system, reacts positively to the gradients of iron ions (II)/(III) and sulfur compounds, and can help At. ferrooxidans to prevent the formation of passivation of chalcopyrite and having both bacteria in combination (At. ferrooxidans and At. thiooxidans), optimizing the ability to oxidize elemental sulfur to sulfuric acid allowing the ferric ion to attack the mineral for getting the release of copper.

\section{Electrochemical potential}

For the electrochemical potential values, it shows a similar value for the tests that had an enrichment of iron oxidizing bacteria and in those in combination with sulfur oxidizing consortium (At. thiooxidans), but when At. thiooxidans is alone, there was a decrease in the values of electrochemical potential. This result, as Rawlings and Johnson (2007) indicated, is due to the non-generation of ferric iron by sulfur oxidizing bacteria, but when At. thiooxidans is accompanied with an iron oxidizing bacteria we observe an increase in the electrochemical potential of the test. This is because the mineral studied was not autoclaved (and thus sterilized), since the manufacturing process does not present any sterilization, and for not to change the physical-chemical composition or galvanic interactions after the sterilization process. Leptospirillum ferrooxidans showed the greatest levels of electrochemical potential (Figure 3), but not the highest extraction of copper (Figure 2). This, according to Stott et al. (2000), is due to Leptospirillum ferrooxidans, which is particularly efficient in the oxidation of ferrous ions to ferric ions and passing them to generate high levels of electrochemical potential, which generates a lower conductivity on the surface of chalcopyrite, generating in turn a lower copper extraction.

Although the values of the electrochemical potential of the tests are very similar, there is a significant difference in the extraction of copper (Figure 2) by different consortia, this contrasts with results reported by Hiroyoshi et al. (2004), who notes that the reaction of leaching of chalcopyrite is known to be very sensitive to the redox potential values, in fact, higher dissolution of chalcopyrite ranges have

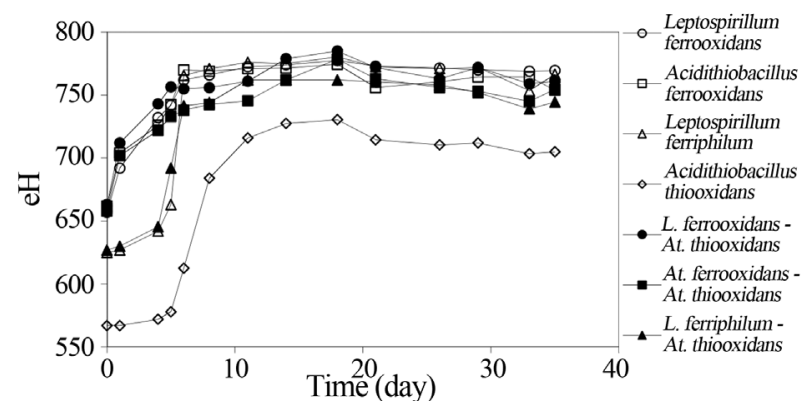

Figure 3 - Level of electrochemical potential. Measurement of variations of electrochemical potential among days in bioleaching tests on flasks. been reported in lower electrochemical potential values at levels of between 450 to $650 \mathrm{mV}$; however testing for major consortia At. ferrooxidans with At. thiooxidans shows the opposite, removing $70 \%$ of copper at the end of the test. This result validates the proposal that At. ferrooxidans has double ability to oxidize iron and sulfur, helping to prevent the formation of the "passivation of chalcopyrite" on the mineral, allowing the spreading of ferric ion on the ore and copper's release

\section{Measurement of $\mathrm{pH}$ in time}

We observe a difference in $\mathrm{pH}$ values over time (Figure 4), showing that by combining the iron oxidizing consortia type with the consortium of At. Thiooxidans, the $\mathrm{pH}$ tends to be lower than when the iron oxidizing consortia are alone ( $L$. ferrooxidans, At. ferrooxidans and $L$. ferriphilum). This, according to Norris et al. (2000) is because the bacteria of the sort Leptospirillum, unable to oxidize sulfur in sulfuric acid, cannot maintain the $\mathrm{pH}$ values in the ranges suitable for leaching. However, while maintaining acidity in the middle, the $\mathrm{pH}$ values for the test with L. ferrooxidans and L. ferriphilum alone, did not rise above of 2.3. This may be because the presence of sulfur oxidizing bacteria in the mineral helped the maintenance of $\mathrm{pH}$ levels.

With regard to the change in $\mathrm{pH}$, the tests are consistent as described by Rawlings and Johnson (2007), who reported that most microbiological applications in the ore are dependent on the presence of microorganisms that oxidize iron (L. ferrooxidans and L. ferriphilum) or iron and sulfur (At. ferrooxidans). The presence of only sulfur oxidizing bacteria for reducing sulfur compounds formed during the dissolution of the mineral ensure its presence in most bioleaching operations, where they play an important role generating acid in processes, which ensures the solubility of ferric ion in the operation. This continues validating that $A t$. ferrooxidans helps prevent formation of the "passivation of chalcopyrite", introducing the combined pools (At. ferrooxidans with At. thiooxidans). Hence lower $\mathrm{pH}$ values increased oxidation of sulfur to sulfuric acid. This result is associated with increased extraction of copper from this test (Figure 2).

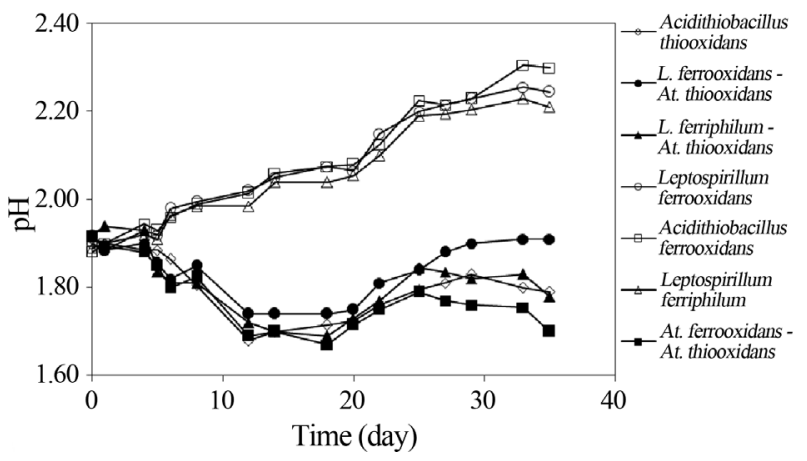

Figure 4 - Level of $\mathrm{pH}$. Change of $\mathrm{pH}$ among days in the bacterial consortia, in bioleaching tests in flasks. 


\section{Changes in bacterial concentration}

The values for the bacterial concentration (Figure 5) were similar in all tests, nevertheless there is a higher bacterial concentration when the consortium At. ferrooxidans is alone than when it is combined with At. Thiooxidans. However, there was a greater extraction of copper by the combination of both bacterial consortia.

\section{Scaling in bioleaching columns}

To validate the study that was performed in flasks, it has been done an escalation of Bioleaching columns (Figure 6) with the consortium that achieved a greater extraction of copper in the test flasks (At. ferrooxidans with At. thiooxidans). There is clearly a difference between this consortium and the control test in the extraction of copper. The overall results of this research are consistent with those described by Parker et al. (2004), who notes that each bioleaching operation presents unique physical and chemical properties due to their mineralogical composition, therefore it can not be extrapolated results of previous deposits, since it is very difficult for two sites present the same mineralogy in full composition of the mineral and can not be performed a generalization.

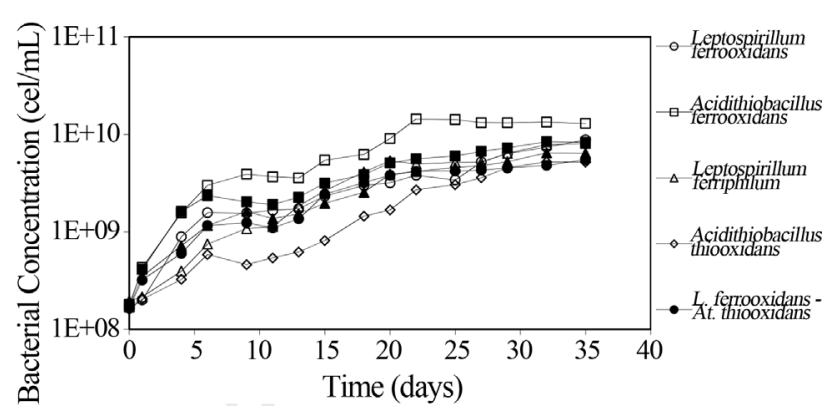

Figure 5 - Level of bacterial concentration. Variation of bacterial number (concentration cel $/ \mathrm{mL}$ ) among days in bioleaching tests on flasks.

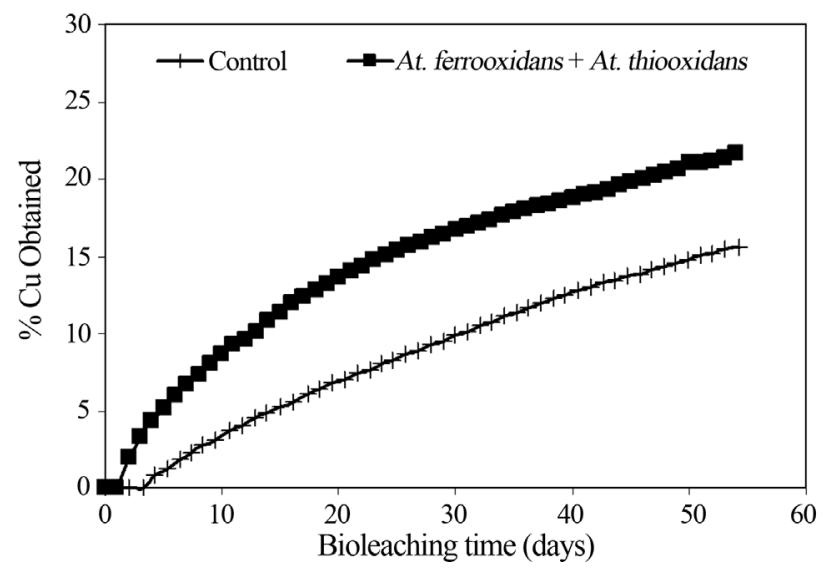

Figure 6 - An escalation in Bioleaching columns. Percentages of extraction of copper columns $1.5 \mathrm{~m}$ by biolixiviation, until 55 days duration and an inoculated amount of $5 \%$ of the solution passed through the column.

\section{Conclusion}

The group found an optimal bacterial consortium for sulphide ore, which is composed mainly with the bacterial species At. ferrooxidans with At. thiooxidans. This consortium achieved a $70 \%$ removal of copper in 35 days compared to the consortium composed of $L$. ferrooxidans with At. thiooxidans (35\% in 35 days). The escalation in bioleaching columns with the bacterias At. ferrooxidans with At. thiooxidans shows the increase in the extraction of copper from the ore, which demonstrates the ability of the consortium chosen and it industrial relevance.

\section{References}

Battaglia F, Morin D, Garcia JL, Ollivier P (1994) Isolation and study of two strains of Leptospirillum-like bacteria from a natural mixed population cultured on a cobaltiferous pyrite substrate. Antonie van Leeuwenhoek 66:295-302.

Coram NJ, Rawlings DE (2002) Molecular relationship between two groups of the genus Leptospirillum and the finding that Leptospirillum ferriphilum sp. nov. dominates South African commercial biooxidation tanks that operate at $40 \mathrm{C}$. Appl Environ Microbiol 68:838-845.

Dreisinger D, Hackl R, Peters E, King J (1995) Passivation of chalcopyrite during oxidative leaching in sulfate media. Hydrometallurgy 39:25-48.

Hiroyoshi N, Kuroiwa S, Miki H, Tsunekawa M, Hirajima T (2004) Synergistic effect of cupric and ferrous ions on active-passive behavior in anodic dissolution of chalcopyrite in sulfuric acid solutions. Hydrometallurgy 74:103-116.

Klauber C, Parker A, van Bronswijk W, Watling H (2001) Sulphur speciation of leached chalcopyrite surfaces as determined by X-ray photoelectron spectroscopy. International Journal of Mineral Processing 62:285-298.

Meyer G, Schneider-Merck T, Böhme S, Sand W (2002) A simple method for investigations on the chemotaxis of A. ferrooxidans and D. vulgaris. Acta Biotechnologica 22:391-399.

Nakamura K, Yudiarto M, Kaneko N, Kurosawa H, Amano Y (1997) A microbial method using whole cells of Thiobacillus thiooxidans for measuring sulphate in waters. Appl Microbiol Biot 48:753-757.

Norris PR, Burton NP, Foulis NAM (2000) Acidophiles in bioreactor mineral processing. Extremophiles 4:71-76.

Okibe N, Johnson DB (2004) Biooxidation of pyrite by defined mixed cultures of moderately thermophilic acidophiles in $\mathrm{pH}$ controlled bioreactors: Significance of microbial interactions. Wiley InterScience 87:574-583.

Parker A, Klauber C, Stott M, Watling H, van Bronswijk W (2004) An X-ray photoelectron spectroscopy study of the mechanism of microbially assisted dissolution of chalcopyrite. In: Tzesos, M., Hatzikioseyan, A., Remoundaki, E. (eds.). Biohydrometallurgy: A Sustainable Technology in Evolution. National Technical University of Athens. Athens p.1011-1022.

Rawlings DE, Johnson DB (2007) The microbiology of biomining: development and optimization of mineral-oxidizing microbial consortia. Microbiology 153:315-324.

Rohwerder T, Gehrke T, Kinzler K, Sand W (2003) Bioleaching review part A. Appl Microbiol Biot 63:239-248. 
Stott MB, Watling HR, Franzmann PD, Sutton D (2000) The role of iron-hydroxy precipitates in the passivation of chalcopyrite during bioleaching. Minerals Engineering 13:11171127.

Tshilombo A, Petersen J, Dixon D (2002) The influence of applied potentials and temperature on the electrochemical response of chalcopyrite during bacterial leaching. Minerals Engineering 15:809-813.

Tuovinen OH, Kelly DP (1973) Studies on the growth of Thiobacillus ferrooxidans. Arch Microbiol 88:285-298.

Watling H (2006) The bioleaching of sulphide minerals with emphasis on copper sulphides - A review. Hydrometallurgy 84:81-108.
Xia L, Tang L, Xia J, Yin C, Cai L, Zhao X, Nie Z, Liu J, Qiu G (2012) Relationships among bioleaching performance, additional elemental sulfur, microbial population dynamics and its energy metabolism in bioleaching of chalcopyrite. Transactions of Nonferrous Metals Society of China 22:192-198.

Xia L, Liu X, Zeng J, Yin C, Gao J, Liu J, Qiu G (2008) Mechanism of enhanced bioleaching efficiency of Acidithiobacillus ferrooxidans after adaptation with chalcopyrite. Hydrometallurgy 92:95-101.

All the content of the journal, except where otherwise noted, is licensed under a Creative Commons License CC BY-NC. 